\title{
Spinal Cord Stimulator Placement in a Patient with Type 2 von Willebrand's Disease
}

\author{
Scott Masson, DO, and Michael Sikorsky, DO
}

We present a case of a 76-year-old female with a history of lumbar post-laminectomy pain syndrome and Type II von Willebrand's disease who underwent successful implantation of a spinal cord stimulator. A consultation with the patient's hematologist was obtained, and antihemophilic factor/von Willebrand factor complex was administered immediately prior to insertion and removal of trial leads. After reporting greater than $90 \%$ pain relief, the patient then underwent permanent implantation with administration of antihemophilic factor/von Willebrand factor complex prior to placement. The epidural space was entered atraumatically, and lead placement was uneventful with minimal resistance met. Leads were tunneled to her right gluteal region, where a pocket was created for her generator. She continues to report good relief without neurological signs of epidural hematoma nearly 6 months post-procedure.

Key words: von Willebrand disease, high-frequency spinal cord stimulator, post-laminectomy pain syndrome

\section{CASE REPORT}

A 76-year-old female with a history of Type II von Willebrand's disease, L2-L5 lumbar laminectomy, and lumbar post-laminectomy pain syndrome presented to the outpatient pain clinic with complaints of low back and left-sided radicular leg pain that was refractory to medical management, physical therapy, and non-neuraxial steroid injection therapy. The patient's activities of daily living were severely compromised due to the nature of her pain. Neuraxial injection therapy was not attempted due to a high likelihood of failure and potentially high costs due to probable need for multiple injections and resultant treatment with expensive blood products antihemophilic factor/recombinant vWF complex, which alone cost $\$ 5740$ (8) per visit in a $70 \mathrm{~kg}$ patient compared to $\$ 18,636$ (9) for spinal cord stimulator implantation with appropriate blood product therapy. As such, a high-frequency spinal cord stimulator was placed to

From : Beaumont Health System, Royal Oak, MI

Author for correspondence: Scott Masson, DO

Address: Beaumont Health System, 3601 W 13 Mile Rd, Royal Oak, MI 48073

E-mail: scott.masson@beaumont.org minimize the number of neuraxial procedures while providing maximal analgesic benefit that would improve the patient's overall quality of life and allow her to resume her normal daily activities. A hematology consult was obtained, and due to the qualitative nature of her coagulopathic condition, 3000 units of antihemophilic factor/von Willebrand factor complex was administered immediately prior to placement and removal of her trial stimulator. Greater than $90 \%$ relief was reported with an associated improvement in activity level. Therefore, a permanent high-frequency spinal cord stimulator was placed. Preoperative antihemophilic factor/von Willebrand factor complex was administered in a fashion similar to that of her trial placement. The epidural space was entered with loss of resistance to air in an atraumatic fashion and both leads were placed at the appropriate levels with minimal resistance. The procedure was uncomplicated, and the patient was discharged on postoperative day zero. The patient's subsequent postoperative course was uncomplicated, and she continues to report greater than $90 \%$ improvement in her functional status and pain scores without sensorimotor signs of epidural hematoma nearly six months post-procedurally. Based on our literature 
search, this case represents the first instance of spinal cord stimulator placement in a patient with von Willebrand disease.

\section{DISCUSSION}

Von Willebrand disease (VWD) is an inherited clotting disorder caused by either a qualitative or quantitative deficiency in von Willebrand factor (VWF). VWF serves 2 main roles related to the coagulation cascade. It facilitates formation of primary platelet plug via binding of platelet Gplb and Gpllb/llla receptors and sub-endothelial collagen, and also serves as a carrier protein for factor VIII, a coagulation factor involved in secondary hemostasis (1). There are 3 main types of VWD: Type 1 (partial quantitative deficiency), Type 2 (qualitative deficiency, 4 additional subtypes based on phenotype), and Type 3 (severe quantitative deficiency) $(1,2)$. Table 1 (1) illustrates the various subtypes of von Willebrand disease and suggested treatment modalities in the perioperative period. While case reports of safe placement of both single shot epidurals and epidural catheters in patients with VWD exist (3-6), a majority of these cases are either in the obstetric population, in which factor VIII levels are increased due to the hormonal changes of pregnancy, or in patients with Type 1 VWD responsive to desmopressin. Additionally, SCS placement necessitates a 14-gauge needle, which is significantly larger than what is typically used for routine epidurals, and can, therefore, increase the risk of epidural hematoma (7).

There is limited information on how best to manage this subset of patients for SCS placement, but this case illustrates that successful placement can be done safely, effectively, and is potentially more cost effective than injection therapy in this subset of patients. However, one should especially consider explantation rates of various types of SCS therapy when contemplating which SCS is best for patients with coagulation disorders. Recent literature suggests that non-rechargeable SCS implant may have lower rate of explantation compared with rechargeable SCS implant (10). Given the paucity of data on the subject, our best recommendation is a thorough preoperative coagulation workup with the involvement of a hematologist prior to proceeding with the procedure.

Table 1. Classification of hereditary von Willebrand Disease (vWD).

\begin{tabular}{|c|c|c|c|c|c|}
\hline Type & Type of defect & $\begin{array}{l}\text { Percentage of } \\
\text { all vWD cases }\end{array}$ & $\begin{array}{c}\text { Inheritance } \\
\text { pattern }\end{array}$ & $\begin{array}{c}\text { Risk of } \\
\text { bleeding } \\
\text { complications }\end{array}$ & Treatment \\
\hline & & & & & Desmopressin \\
\hline 1 & Quantitative & $60 \%-80 \%$ & Autosomal dominant & Low & $\begin{array}{l}\text { Some patients with } \\
\text { contraindications, poor } \\
\text { response, or anticipation of } \\
\text { multiple doses may require } \\
\text { factor concentrates }\end{array}$ \\
\hline \multirow{5}{*}{$2(\mathrm{~A}, \mathrm{~B}, \mathrm{M}, \mathrm{N})$} & Qualitative & \multirow{5}{*}{$10 \%-30 \%$} & $\begin{array}{c}\text { A, B, M: Autosomal } \\
\text { dominant }\end{array}$ & \multirow{5}{*}{$\begin{array}{l}\mathrm{A}, \mathrm{B}, \mathrm{M}, \mathrm{N}: \text { Low to } \\
\text { moderate }\end{array}$} & $\begin{array}{l}\text { 2A: Desmopressin (unless } \\
\text { severe form of disease or } \\
\text { poor response) }\end{array}$ \\
\hline & A: Reduced platelet binding & & \multirow{4}{*}{$\begin{array}{l}\text { N: Autosomal } \\
\text { Recessive }\end{array}$} & & \multirow{4}{*}{$\begin{array}{l}\mathrm{B}, \mathrm{M}, \mathrm{N} \text { : factor } \\
\text { concentrates. Desmopressin } \\
\text { is contraindicated in } \\
\text { Subtype 2B because it can } \\
\text { worsen thrombocytopenia }\end{array}$} \\
\hline & $\begin{array}{c}\text { B: Increased platelet binding } \\
\text { leading to increased clearance of } \\
\text { vWF from plasma }\end{array}$ & & & & \\
\hline & M: Reduced platelet binding & & & & \\
\hline & $\mathrm{N}$ : Reduced factor VIII binding & & & & \\
\hline 3 & Severe quantitative & $1 \%-5 \%$ & & High & Factor concentrates \\
\hline
\end{tabular}


SCS Placement in a Patient with Type 2 von Willebrand's Disease

\section{REFERENCES}

1. Mazzeffi MA, Stone ME. Perioperative management of von Willebrand disease: A review for the anesthesiologist. J Clin Anesthesia 2011; 23:418-426.

2. Khan TW, Yacoub A. Pitfalls in interventional pain medicine: Hyponatremia after DDAVP for a patient with von Willebrand's Disease undergoing an epidural steroid injection. Case Reports in Anesthesiology 2017; 1:1-3.

3. Telang PR, Vrooman BM. Lumbar epidural steroid injection in a patient with Von Willebrand's disease. Proceedings of the American Academy of Pain Medicine Annual Meeting, Palm Springs, Calif, USA, February 2012.

4. Cohen S, Zada Y. Neuraxial block for von Willebrand disease. Anaesthesia 2001; 56:397-397.

5. Cohen S, Daitch J, Amar D, Goldiner PL. Epidural analgesia for labor and delivery in a patient with von Willebrand's Disease. Obstetric Anesthesia Digest 1989; 9:175.
6. Jones BP, Bell EA, Maroof M. Epidural labor analgesia in parturient with von Willebrand's Disease type IIA and severe preeclampsia. Anesthesiology 1999; 90:1219-1220.

7. Manchikanti L, Frank J, Benyamin R, Caraway D, Kaye A, Helm S, Wargo B, Hansen H, Parr A, Singh V, Swicegood J, Smith H, Schultz D, Malla Y, Hirsch J. Assessment of bleeding risk of interventional techniques: A best evidence synthesis of practice patterns and perioperative management of anticoagulant and antithrombotic therapy. Pain Physician 2013; 16:261-318.

8. Franco-Martinez C. UHS inpatient pharmacy clotting factors reference table.2014 Retrieved from https://www.universityhealthsystem.com/ /media/files/clinical-pathways/clotting-factor-table-0814.pdf?la=en.

9. Farber, S, Han, J, Elsamadisy, A, Hussaini Q, Yang S, Pagadala P, Parente B, Xie J, Lad S. Long-term cost utility of spinal cord stimulation in patients with failed back surgery syndrome. Pain Physician 2017; 20:797-805. 
